\title{
Metabolism of Fibrinogen in Cirrhosis of the Liver
}

\author{
G. N. Trtgat, D. Collen, and M. Verstraete \\ From the Laboratory of Blood Coagulation, Department of Medicine, \\ University of Leuven, Leuven, Belgium
}

A B S T RACT The metabolism of human fibrinogen labeled with radioactive iodine was studied in 50 patients with documented cirrhosis of the liver and in 35 healthy control subjects. Results in cirrhotic subjects were the following: plasma volume $47 \pm 10 \mathrm{ml} / \mathrm{kg}$; plasma fibrinogen concentration $250 \pm 102 \mathrm{mg} / 100 \mathrm{ml}$; total plasma fibrinogen pool $118 \pm 59 \mathrm{mg} / \mathrm{kg}$, representing $0.73 \pm 0.10$ of the total body pool; fibrinogen half-life $2.99 \pm 0.59$ days; fractional catabolic rate $0.34 \pm 0.09$ of the plasma pool per day; absolute catabolic rate $39 \pm 20 \mathrm{mg} / \mathrm{kg}$ per day; fractional transcapillary efflux rate $0.82 \pm 0.30$ of the plasma pool per day. Results in the control subjects were the following: plasma volume $42 \pm 7 \mathrm{ml} / \mathrm{kg}$; plasma fibrinogen concentration $284 \pm 71 \mathrm{mg} / 100 \mathrm{ml}$; total plasma fibrinogen pool $119 \pm 40 \mathrm{mg} / \mathrm{kg}$, representing $0.72 \pm 0.07$ of the total body pool; fibrinogen half-life $4.14 \pm 0.56$ days; fractional catabolic rate $0.24 \pm 0.04$ of the plasma pool per day; absolute catabolic rate $28 \pm 9$ $\mathrm{mg} / \mathrm{kg}$ per day; fractional transcapillary efflux rate 0.60 \pm 0.26 of the plasma pool per day.

A significant difference between cirrhotics and controls was observed for plasma volume, fibrinogen halflife, fractional and total catabolic rates, and transcapillary efflux rate. During heparinization of 10 cirrhotic patients the fibrinogen half-life was prolonged from $3.15 \pm 0.69$ to $4.59 \pm 0.79$ days. This was associated with a rise in plasma fibrinogen in six out of eight patients. Heparinization did not influence the fibrinogen half-life in five control subjects. Inhibition of the fibrinolytic system in 17 patients resulted in prolongation of the plasma radioactivity half-life of more than 1 day in only three patients, an incidence comparable with that in five control subjects.

These results strongly support the concept of accelerated fibrinogen consumption by a process of disseminated intravascular coagulation in cirrhosis of the liver.

This work was presented in part at the National Meeting of the American Federation for Clinical Research, Atlantic City, N. J. May 1970. During this study Dr. Tytgat and Dr. Collen were recipients of a grant from the Belgian National Fund for Scientific Research.

Received for publication 10 December 1970 and in revised form 22 February 1971.

\section{INTRODUCTION}

Several mechanisms are thought to be involved in the pathogenesis of the complex coagulation and fibrinolytic abnormalities in severe liver disease. Low levels of fibrinogen among other coagulation proteins in cirrhosis are classically ascribed to insufficient hepatic synthesis, although production of a defective fibrinogen molecule cannot entirely be excluded. Thrombocytopenia appears to be related to excessive pooling of platelets in the congestive splenic sinusoids (1), whereas the occasional functional alterations of platelets remain poorly understood (2-5). Excessive fibrinolytic activity is explained by deficient clearing of plasminogen activator and insufficient production of fibrinolytic inhibitors $(6,7)$. However these mechanisms frequently fail to explain all aspects of the hemorrhagic syndrome in cirrhosis of the liver.

There is a similarity between the complex coagulation and fibrinolytic disturbances in cirrhosis and those observed in clinical or experimental disseminated intravascular coagulation (8-10). To substantiate the hypothesis of chronic disseminated intravascular coagulation, potentially associated with secondary activation of the fibrinolytic system, the metabolism of labeled fibrinogen was analyzed in 50 patients with cirrhosis of the liver.

The effect on the turnover of labeled fibrinogen of in vivo inhibition of the coagulation system by heparin was studied in 10 patients, and that of in vivo inhibition of the fibrinolytic system by tranexamic acid was studied in 17 patients.

\section{METHODS}

Labeled fibrinogen. Each batch of homologous human fibrinogen (fraction I-2F) was prepared from freshly frozen ACD plasma of at least six healthy blood donors $(11,12)$. The clottability of the fibrinogen preparations was at least $95 \%$. Labeling with ${ }^{181} \mathrm{I}$ or ${ }^{125} \mathrm{I}$ was performed according to McFarlane (13). Unbound iodine was removed by passage through an Amberlite IRA 401 column. The content of remaining free iodine was less than $1 \%$. The labeled protein solution was sterilized through a Jena G5M filter. Eight fibrinogen batches were used in 23 labeling procedures. The substitution level in the labeled fibrinogen varied from 0.09 
to 0.40 ( $\overline{\mathrm{m}} 0.235$ ) atoms of iodine per molecule of fibrinogen $(\mathrm{mol} w \mathrm{wt}=330,000)$. After labeling, $90-96 \%$ of the radioactivity was recovered in the fibrin clot (11).

Immunoelectrophoresis (14) revealed a single identical precipitation line before and after iodination, and radioautography showed concentration of isotope in the precipitation line (Fig. 1). Each batch of labeled fibrinogen was used simultaneously in cirrhotics and controls and was found to give comparable half-life values in control subjects.

Metabolic studies. The control series consisted of 30 male and 5 female healthy subjects, who performed their usual activities. The cirrhotic group consisted of 35 males and 15 females, who were hospitalized or ambulatory patients. The diagnosis of cirrhosis of the liver in different stages of evolution, was documented by physical examination and laboratory findings, and was proven in all but five patients by peritoneoscopy and by liver biopsy. The cirrhosis of the liver was of the postnecrotic type in 25 patients and of the portal (alcoholic) type in 18 patients.

A clinical diagnosis of cirrhosis was accepted on the basis of long-standing jaundice, unequivocal signs of ascites and portal hypertension, and biochemical evidence of liver cell failure. None of the patients had any noticeable bleeding during the experimental period, as checked clinically and by daily hematocrit determination. Some patients suffering from chronic fluid retention were on a low salt diet, occasionally supplemented with diuretics as individually specified. ${ }^{1} \mathrm{~A}$ practically constant body weight was maintained for all patients throughout the study.

At least 1 day before injection of the labeled protein and during the entire procedure, the thyroid was saturated by daily administration of 30 drops of saturated $\mathrm{KI}$ solution or $500 \mathrm{mg} \mathrm{KI}$ in order to inhibit thyroidal uptake of labeled iodine. Exactly $10 \mathrm{~min}$ after careful intravenous injection of approximately $30-40 \mu \mathrm{Ci}$ of the labeled protein, the first blood sample was taken from the opposite arm. Subsequent blood samples were drawn, approximately each day, for at least 11 and up to 21 days. Blood specimens for radioactivity and coagulation assays were collected in 0.2 $\mathrm{ml} 10 \%$ EDTA with $0.1 \mathrm{ml}$ aprotinin (Trasylol, ${ }^{2} 5000 \mathrm{KIU} /$ $\mathrm{ml}$ ) per $10 \mathrm{ml}$ blood. Blood for fibrinolytic assays was collected in precooled plastic or siliconized tubes, containing $0.5 \mathrm{ml} 2.5 \%$ potassium oxalate per $4.5 \mathrm{ml}$ blood. $1 \mathrm{ml}$ aliquots of each of the following were pipetted in duplicate into counting tubes: radioactive plasma, plasma supernatants after protein precipitation with an equal volume of $10 \%$ trichloroacetic acid, fibrin solubilized in alkaline urea (11), and urine. After completion of the experiment, the radioactive aliquots were measured in a well-type scintillation counter (gamma/guard; Autowell counting system ${ }^{8}$ ) with a sensitivity of approximately $600,000 \mathrm{cpm} / \mu \mathrm{Ci}$ against a background of $30 \mathrm{cpm}$.

Anticoagulation was performed by infusion of Na-heparin dissolved in $5 \%$ glucose solution, using an infusion pump. The amount of heparin was individually adjusted to prolong the whole blood clotting time at least 2-4 times. Inhibition of the fibrinolytic system was realized by daily oral administration (three times) of $1 \mathrm{~g}$ of tranexamic acid (trans-

\footnotetext{
${ }^{1}$ Additional data deposited with C. C. M. Information Corp., National Auxiliary Publications Inc., New York. No. 01399.

${ }^{2}$ Trasylol, Bayer, Leverkusen, Germany.

8 Tracerlab, Mechelen, Belgium.
}
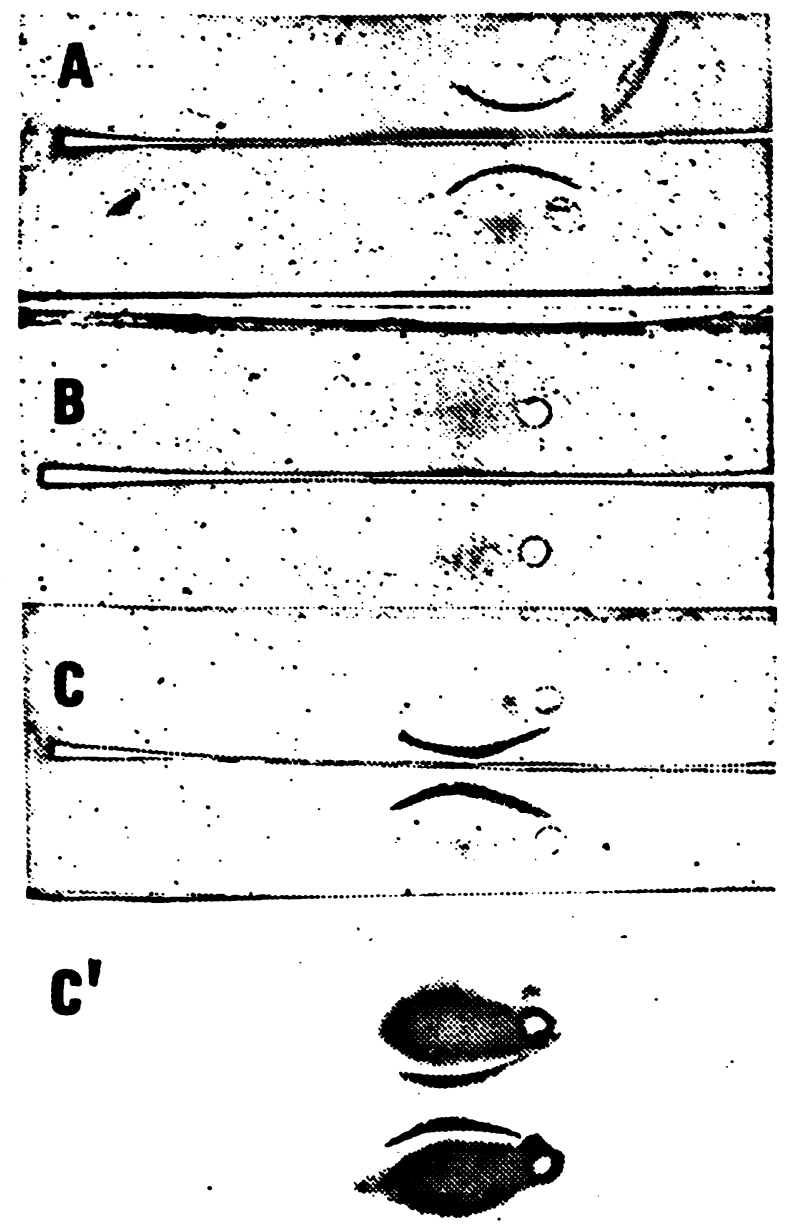

FIGURE 1 Immunoelectrophoresis of fibrinogen in agar. (A) $5 \mu 1$ unlabeled fibrinogen $2 \%$ vs. $0.1 \mathrm{ml}$ rabbit anti-human fibrinogen antiserum. (B) $5 \mu$ l unlabeled fibrinogen $2 \%$ vs. $0.1 \mathrm{ml}$ rabbit anti-human serum antiserum. (C) $5 \mu \mathrm{l}$ labeled fibrinogen vs. $0.1 \mathrm{ml}$ rabbit anti-human fibrinogen antiserum. $\left(C^{\prime}\right)$ Radioautography of $C$.

4-aminomethyl cyclohexane-1-carboxylic acid, AMCA), a potent inhibitor of plasminogen activation (15).

Analysis of tracer data. The plasma radioactivity data, expressed as fractions of the first plasma samples, were fitted with a sum of two exponential terms, $x(t)=C_{1} e^{-a} 1^{t}$ $+\mathrm{C}_{2} \mathrm{e}^{-\mathrm{a} 2 \mathrm{t}}$ by graphical curve peeling on semilogarithmic paper. The fractional catabolic rate constant $\left(k_{10}\right)$, the extravascular-intravascular distribution ratio $(\mathrm{EV} / \mathrm{IV})$, and the fractional transcapillary efflux $\left(k_{12}\right)$ and reflux $\left(k_{21}\right)$ rate constants were calculated from the plasma radioactivity disappearance by two-compartmental analysis (16)..$^{5}$ The absolute catabolic rate was determined by multiplying the fractional catabolic rate by the corresponding mean plasma fibrinogen pool. Plasma volume determinations were made

\footnotetext{
${ }^{4} \mathrm{AMCA}$ was kindly supplied by Kabi AB, Stockholm, Sweden.

${ }^{5}$ Collen, D., G. N. Tytgat, H. Claeys, and R. Piessens. Metabolism and distribution of fibrinogen in physiological conditions in humans. To be published.
} 
TABLE I

Metabolism and Distribution of Fibrinogen in 35 Healthy

\begin{tabular}{|c|c|c|c|c|c|c|c|}
\hline & \multirow[b]{2}{*}{ Age } & \multirow{2}{*}{$\begin{array}{c}\text { Body } \\
\text { weight }\end{array}$} & \multirow{2}{*}{$\begin{array}{l}\text { Plasma } \\
\text { volume }\end{array}$} & \multirow{2}{*}{$\begin{array}{c}\text { Plasma } \\
\text { fibrinogen }\end{array}$} & \multirow{2}{*}{$\begin{array}{l}\text { Plasma } \\
\text { fibrinogen } \\
\text { pool }\end{array}$} & \multicolumn{2}{|c|}{$\begin{array}{r}\text { Fibrinogen } \\
\text { tracer data: } \\
x(t)=C_{1} e^{-a_{1} t} \\
+C_{2} e^{-a_{2} t}\end{array}$} \\
\hline & & & & & & $\mathrm{C}_{1}$ & $a_{1}$ \\
\hline & $y r$ & kg & $m l / k g$ & $\begin{array}{c}\mathrm{mg} / \\
100 \mathrm{ml}\end{array}$ & $\mathrm{mg} / \mathrm{kg}$ & & \\
\hline \multicolumn{8}{|l|}{$\begin{array}{l}\text { Control } \\
\quad \text { subjects }\end{array}$} \\
\hline Average & 38 & 69 & 42 & 284 & 119 & 0.67 & 0.169 \\
\hline SD & 15 & 10 & 7 & 71 & 40 & 0.08 & 0.023 \\
\hline \multicolumn{8}{|l|}{$\begin{array}{l}\text { Cirrhotic } \\
\text { patients }\end{array}$} \\
\hline Average & 58 & 68 & 47 & 250 & 118 & 0.69 & 0.243 \\
\hline SD & 11 & 10 & 10 & 102 & 59 & 0.11 & 0.062 \\
\hline \multicolumn{8}{|l|}{$t$ test } \\
\hline$(P$ value $)$ & $<0.001$ & & $<0.05$ & & & & \\
\hline
\end{tabular}

from the dilutions of the injected labeled material in the 10 min sample.

Laboratory assays. The following coagulation and fibrinolytic parameters were determined: clotting time (17), onestage prothrombin time (18), Owren time (19), factor VII-X (20), factor V (21), thrombin time (22), fibrinogen $(11,23)$, platelet count (24), plasminogen (25), euglobulin fibrinolytic activity on unheated fibrin plates (26), and euglobulin clot lysis time (27). The following liver function tests were performed according to standard laboratory procedures: serum protein assay and paper electrophoresis, serum bilirubin, alkaline phosphatase (Bodansky units), and serum glutamic-oxalacetic and glutamic-pyruvic transaminases.

Statistics. Statistical calculations were performed according to Bailey (28) on a digital computer (IBM 1800).

\section{RESULTS}

Fibrinogen metabolism in control subjects. Clinical data, fibrinogen tracer data, and calculated metabolic parameters in 30 male and 5 female control subjects ${ }^{1}$ are summarized in Table $\mathrm{I}$. The average albumin concentration was $3.9 \pm 0.5 \mathrm{~g} / 100 \mathrm{ml}$, whereas the mean gamma globulin level was $1.1 \pm 0.2 \mathrm{~g} / 100 \mathrm{ml}$. Liver function tests (alkaline phosphatase, bilirubin, transaminases) and one-stage prothrombin time were within normal limits in all subjects. The mean venous hematocrit, leukocyte, and platelet counts were $44 \pm 4 \%, 6600$ $\pm 1100 / \mathrm{mm}^{3}$, and $221,000 \pm 51,000 / \mathrm{mm}^{3}$, respectively. The average plasma fibrinogen was $284 \pm 71 \mathrm{mg} / 100$ $\mathrm{ml}$, or $119 \pm 40 \mathrm{mg} / \mathrm{kg}$.

Results of a representative metabolic study are visualized in Fig. 2. The clottable radioactivity measured in 10 controls decreased parallel to the plasma radioactivity.
Whole body counts in three subjects revealed a parallel decay of total body and plasma radioactivity.

The mean value of the equation describing the plasma radioactivity decay curve was $x(t)=0.67 \mathrm{e}^{-0.169 t}$ $+0.33 \mathrm{e}^{-1.44} \mathrm{t}$. The mean fibrinogen half-life for men and women was 4.17 and 3.96 days, respectively; the overall mean was $4.14 \pm 0.56$ days. The mean fractional catabolic rate was $0.24 \pm 0.04$ of the plasma pool per day. The average absolute catabolic rate was $1.94 \pm 0.59$ $\mathrm{g} /$ day or $28 \pm 9 \mathrm{mg} / \mathrm{kg}$ per day. The mean extravascular-intravascular radioactivity distribution ratio was $0.41 \pm 0.15$ with a corresponding intravascular fraction of $0.72 \pm 0.07$. The average transcapillary efflux rate was $0.60 \pm 0.26$, and the average fractional reflux rate was $1.02 \pm 0.39$. No correlation was found between the plasma fibrinogen concentration and half-life nor between the plasma fibrinogen concentration or pool size and the fractional catabolic rate.

Anticoagulation of five control subjects by monitored heparin infusion during 4 days did not influence the decay of plasma radioactivity. ${ }^{5}$ Inhibition of the fibrinolytic system by daily oral administration of tranexamic acid for 4 days resulted in one (R. G.) out of five subjects in a prolongation of plasma radioactivity half-life from 3.6 to 4.3 days.

Fibrinogen metabolism in cirrhosis of the liver. Clinical data, fibrinogen tracer data, and calculated metabolic parameters in 35 male and 15 female patients ${ }^{1}$ with cirrhosis of the liver are summarized in Table I. The average albumin concentration was $2.9 \pm 0.4 \mathrm{~g} / 100 \mathrm{ml}$, whereas the mean gamma globulin level was $2.1 \pm 1.0 \mathrm{~g} /$ $100 \mathrm{ml}$. The albumin concentration was less than 3.0 
Controls and 50 Patients with Cirrhosis of the Liver

\begin{tabular}{|c|c|c|c|c|c|c|c|c|}
\hline & & & & & lated met & parame & & \\
\hline & $\begin{array}{l}\text { tracer } \\
(t)=C\end{array}$ & & $F_{-1}$ & $1-5$ & nte & Distr & $\begin{array}{l}\text { ution } \\
\text { io }\end{array}$ & \\
\hline $\mathrm{C}_{2}$ & $a_{2}$ & $t_{1}$ for $a_{1}$ & $k_{10}$ & $k_{12}$ & $k_{21}$ & $\overline{\mathrm{IV}}$ & IV & rate \\
\hline & & days & & & & & & $\begin{array}{c}m g / k g / \\
\text { per day }\end{array}$ \\
\hline 0.33 & 1.44 & 4.14 & 0.24 & 0.60 & 1.02 & 0.41 & 0.72 & 28 \\
\hline 0.08 & 0.60 & 0.56 & 0.04 & 0.26 & 0.39 & 0.15 & 0.07 & 9 \\
\hline 0.31 & 2.08 & 2.99 & 0.34 & 0.82 & 1.51 & 0.40 & 0.73 & 39 \\
\hline 0.11 & 0.76 & 0.59 & 0.09 & 0.30 & 0.57 & 0.20 & 0.10 & 20 \\
\hline & & $<0.001$ & $<0.001$ & $<0.001$ & $<0.001$ & & & $<0.05$ \\
\hline
\end{tabular}

$\mathrm{g} / 100 \mathrm{ml}$ in approximately half the patients, whereas 32 patients had a gamma globulin level above $1.5 \mathrm{~g} / 100 \mathrm{ml}$. An elevated alkaline phosphatase value was present in 21 , and a total bilirubin above $1.5 \mathrm{mg} / 100 \mathrm{ml}$ was found in 26 patients. 12 patients had transaminase levels higher than twice the normal limit. A prolonged one-stage prothrombin time was present in 35 cirrhotics. The mean venous hematocrit, leukocyte, and platelet counts were, respectively : $38 \pm 7 \%, 5200 \pm 2000 / \mathrm{mm}^{3}$, and 125 ,$000 \pm 62,000 / \mathrm{mm}^{3}$. A platelet count inferior to $150,000 /$ $\mathrm{mm}^{3}$ was observed in 31 patients. The average plasma äbrinogen was $250 \pm 102 \mathrm{mg} / 100 \mathrm{ml}$ or $118 \pm 59 \mathrm{mg} / \mathrm{kg}$.

The mean value of the equation describing the plasma radioactivity decay curve was $x(t)=0.69 \mathrm{e}^{-0.243 t}+$

TABLE II

Influence of Heparin Anticoagulation on the Half-Life of Fibrinogen in Patients with Cirrhosis of the Liver

\begin{tabular}{|c|c|c|c|c|c|c|c|c|c|c|c|c|}
\hline Patient & Age & $\begin{array}{l}\text { One- } \\
\text { stage } \\
\text { pro- } \\
\text { throm- } \\
\text { bin }\end{array}$ & $\begin{array}{c}\text { Owren } \\
\text { time }\end{array}$ & $\begin{array}{c}\text { Factor } \\
\text { V }\end{array}$ & $\begin{array}{l}\text { Factor } \\
\text { VII-X }\end{array}$ & $\begin{array}{c}\text { Mean } \\
\text { platelets } \\
\text { before } \\
\text { heparin- } \\
\text { ization }\end{array}$ & $\begin{array}{c}\text { Mean } \\
\text { platelets } \\
\text { during } \\
\text { heparin- } \\
\text { ization }\end{array}$ & $\begin{array}{l}\text { Intra- } \\
\text { vascular } \\
\text { fraction } \\
\text { of } \mathrm{Fg}\end{array}$ & $\begin{array}{l}\text { Mean } \\
\text { plasma } \\
\text { fibrin- } \\
\text { ogen } \\
\text { before } \\
\text { heparin- } \\
\text { ization }\end{array}$ & $\begin{array}{l}\text { Mean } \\
\text { plasma } \\
\text { fibrin- } \\
\text { ogen } \\
\text { during } \\
\text { heparin- } \\
\text { ization }\end{array}$ & $\begin{array}{c}\mathrm{Fg}-\mathrm{t}_{\mathbf{l}} \\
\text { before } \\
\text { heparin- } \\
\text { ization }\end{array}$ & $\begin{array}{c}\mathrm{Fg}-\mathrm{t}_{\mathrm{i}} \\
\text { during } \\
\text { heparin- } \\
\text { ization }\end{array}$ \\
\hline & $y r$ & $\%$ & $\%$ & $\%$ & $\%$ & $\underset{m^{3}}{\times 10^{-3} /}$ & $\begin{array}{c}\times 10^{-3} / \\
m^{2}\end{array}$ & $\%$ & $\begin{array}{c}\mathrm{mg} / \\
100 \mathrm{ml}\end{array}$ & $\begin{array}{c}m g / \\
100 m l\end{array}$ & days & days \\
\hline V. K. & 78 & 26 & 24 & 50 & 25 & 114 & - & 0.54 & 142 & 218 & 2.4 & 5.0 \\
\hline I. M. & 56 & 66 & 48 & 58 & 58 & 46 & 52 & 0.75 & 183 & 231 & 3.2 & 5.1 \\
\hline C. J. & 40 & 33 & 38 & 33 & 29 & 68 & - & 0.58 & 91 & - & 4.8 & 5.7 \\
\hline B. A. & 47 & 29 & 30 & 33 & 31 & 46 & 67 & 0.72 & 77 & 88 & 3.2 & 4.3 \\
\hline D. R. & 31 & 46 & 72 & 70 & 59 & 160 & - & 0.78 & 484 & 556 & 2.6 & 4.6 \\
\hline V. J. & 65 & 40 & 65 & 40 & 85 & 48 & 53 & 0.68 & 282 & 360 & 2.5 & 3.5 \\
\hline G. F. & 44 & 38 & 55 & 42 & 50 & 94 & 86 & 0.84 & 330 & 396 & 2.8 & 3.3 \\
\hline V. J. & 62 & 28 & 40 & 30 & 31 & 96 & 99 & 0.86 & 278 & - & 3.7 & 5.1 \\
\hline B. J. & 57 & 33 & 47 & 30 & - & 63 & 63 & 0.73 & 168 & 176 & 3.4 & 5.3 \\
\hline V. G. & 52 & 40 & 34 & 38 & 46 & 70 & 78 & 0.90 & 174 & 178 & 2.9 & 4.0 \\
\hline Mean & & & & & & & & 0.74 & 221 & & 3.15 & 4.59 \\
\hline SD & & & & & & & & & & & 0.69 & 0.79 \\
\hline
\end{tabular}




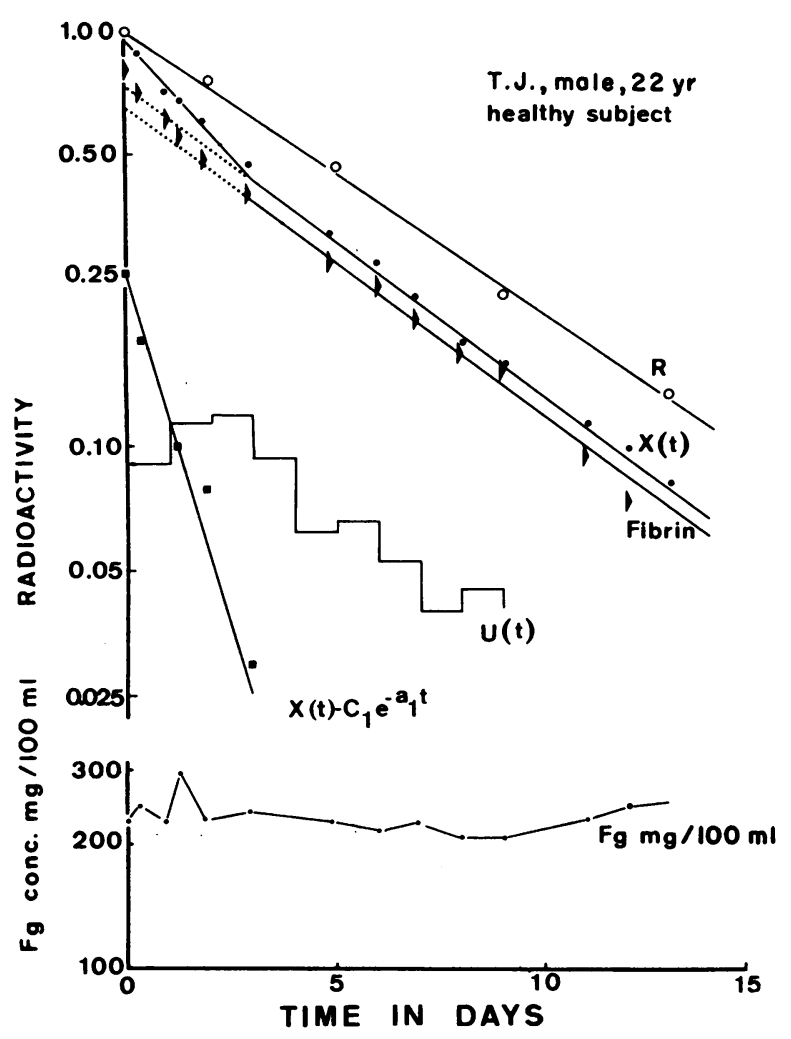

FIgURE 2 Fibrinogen metabolism in a control subject. $x(t)$, - plasma radioactivity; fibrin, clottable radioactivity; $U(t)$, fractional daily urinary excretion of label; $R$, total body radioactivity (whole body count) $\mathrm{Fg}, \mathrm{mg} / 100 \mathrm{ml}$, fibrinogen concentration in plasma. Graphical curve peeling in two exponential functions $x(t)=C_{1} e^{-\mathbf{a} 1 t}+C_{2} e^{-\mathbf{2} 2 t}$. The straight linear terminal portion of the plasma radioactivity $x(t)$, is extrapolated to the ordinate to obtain the intercept $C_{1}$. The slope of this line is $-a_{1}$. By subtracting the extrapolated line from the original curve $\left[x(t)-C_{1} e^{-a_{1} t}\right]$, a new line is obtained $\left[\mathrm{C}_{2} \mathrm{e}^{-\mathrm{a}_{2} t}\right]$ for which the slope $-\mathrm{a}_{2}$ and intercept value $\mathrm{C}_{2}$ are determined.

$0.31 \mathrm{e}^{-2.08 t}$. The mean fibrinogen half-lives for men and women were, respectively, 3.02 and 2.90 days, and the over-all mean was $2.99 \pm 0.59$ days. The mean fractional catabolic rate was $0.34 \pm 0.09$ of the plasma pool per day. The average absolute catabolic rate was 2.66 $\pm 1.43 \mathrm{~g} /$ day or $39 \pm 20 \mathrm{mg} / \mathrm{kg}$ per day. The mean extravascular-intravascular radioactivity distribution ratio was $0.40 \pm 0.20$ with a corresponding intravascular fraction of $0.73 \pm 0.10$. The average fractional transcapillary efflux rate was $0.82 \pm 0.30$, and the average fractional reflux rate was $1.51 \pm 0.57$.

The plasma fibrinogen concentration was positively correlated with the serum albumin concentration $(r=$ $0.304, P<0.05)$ and the factor $\mathrm{V}$ level $(\mathrm{r}=0.499$, $P<0.001)$. Neither the plasma fibrinogen concentration nor the plasma fibrinogen pool (milligrams per kilogram) was correlated with body weight. A significant negative correlation was found between age and plasma fibrinogen concentration $(r=-0.306, P<0.05)$ or absolute catabolic rate (milligrams per kilogram per day) $(r=-0.293, P<0.05)$, but not between age and half-life or fractional catabolic rate. The plasma fibrinogen concentration, but not the plasma fibrinogen pool, was correlated with the fibrinogen half-life $(r=0.284$, $P<0.05)$. No correlation was found between the fractional catabolic rate and the plasma fibrinogen concentration or plasma fibrinogen pool.

Clinical data, laboratory results, and fibrinogen turnover data in patients with cirrhosis of the liver compared with the control population. The mean age of the cirrhotic patients was significantly higher compared with the control value $(P<0.001)$. The cirrhotic serum albumin concentration was significantly lower, whereas the cirrhotic serum gamma globulin concentration was significantly higher than the corresponding control value $(P<0.001)$.

Venous hematocrit, white blood cell count, and platelet count were all significantly decreased in the cirrhosis group, compared with the corresponding value of the

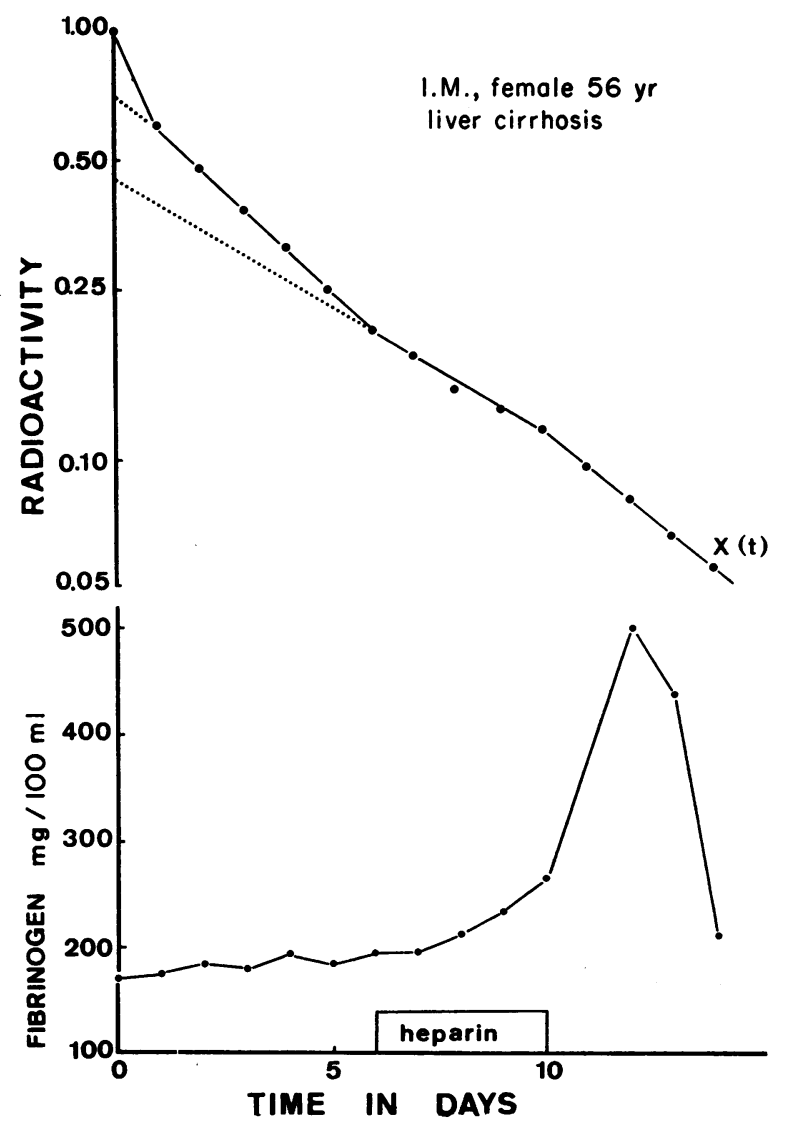

Figure 3 Fibrinogen metabolism in a patient with postnecrotic cirrhosis before and during anticoagulation. $x(t)$, plasma radioactivity. 
control series $(P<0.01)$. The slightly increased plasma volume (milliliters per kilogram) in cirrhotic patients was statistically different from the corresponding control value $(P<0.05)$. The average plasma fibrinogen concentration and pool size in cirrhotic patients were not different from the corresponding control values. A practically identical portion of the total fibrinogen pool was confined to the intravascular compartment for both series. A highly significant difference was noted for the fibrinogen half-life and for the fractional catabolic rate between the cirrhotic and the control population $(P<0.001)$. As expected, the average quantity of fibrinogen catabolized daily was higher in the cirrhotic patients compared with the control group $(P<0.05)$. The average transcapillary reflux and efflux rates were significantly higher in the cirrhotic patients $(P<0.001)$.

Influence of inhibition of the coagulation and fibrinolytic system on the fibrinogen kinetics in cirrhosis. Anticoagulation during 4 days was performed by monitored infusion of heparin. The results of heparin anticoagu- lation on the fibrinogen half-life in 10 patients with postnecrotic or portal (alcoholic) cirrhosis of the liver are summarized in Table II. The evolution of the plasma radioactivity and pertinent coagulation parameters are exemplified for two of these patients in Figs. 3 and 4. Heparin anticoagulation induced a prolongation of the fibrinogen half-life of 1 day or more in 8 out of 10 patients. A concomitant rise in plasma fibrinogen was found in six out of eight patients despite possible heparin interference with the fibrinogen assay. No changes were observed in mean circulating platelet level during the anticoagulation period. The influence of heparin anticoagulation in a patient with primary biliary cirrhosis is visualized in Fig. 5. This fibrinogen turnover study is mentioned separately because the biochemical, histological, and coagulation data in this patient were distinctly different from the common findings in cirrhosis.

Inhibition of the fibrinolytic system during 4 days was performed by daily oral administration of $3 \mathrm{~g}$ tra-

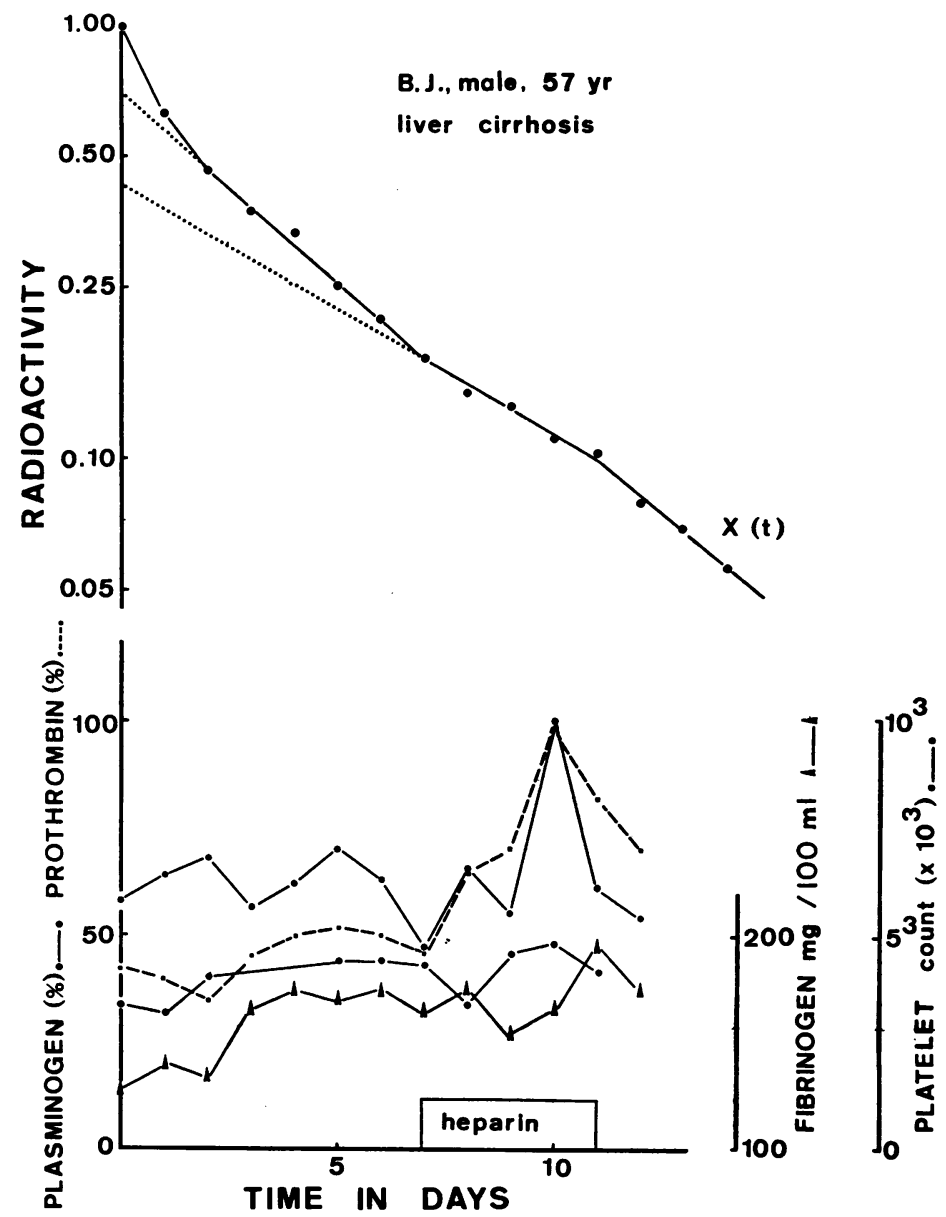

Figure 4 Fibrinogen metabolism in a patient with postnecrotic cirrhosis before and during anticoagulation. $x(t)$, plasma radioactivity. 


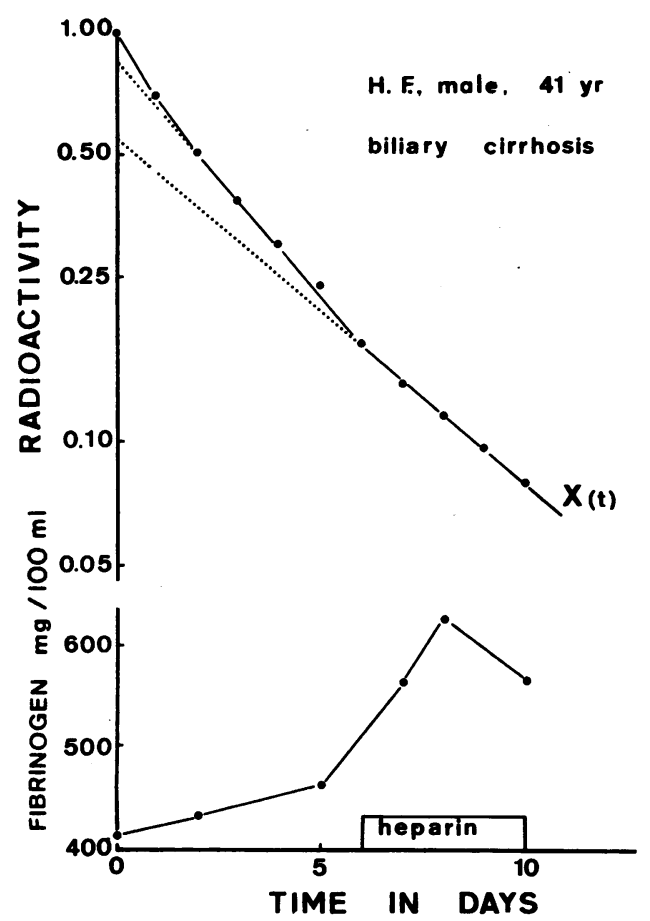

FIgURE 5 Fibrinogen metabolism in a patient with primary biliary cirrhosis before and during anticoagulation. $x(t)$, plasma radioactivity.

nexamic acid. Adequate systemic fibrinolytic inhibition was judged from pronounced interference with the plasminogen assay. The results of fibrinolytic inhibition on the fibrinogen half-life in 17 patients with postnecrotic or portal (alcoholic) cirrhosis of the liver are summarized in Table III. In 7 of the 17 patients, fibrinolytic inhibition had no influence on the fibrinogen disappearance curve. A prolongation of the fibrinogen halflife of 1 day or more was observed in three patients, and of less than 1 day in five patients. The most pronounced half-life prolongation is exemplified for one of them in Fig. 6. A rise in circulating plasma fibrinogen during fibrinolytic inhibition was never observed even in the presence of apparent prolongation of the plasma radioactivity half-life. Acceleration of the plasma radioactivity decay during fibrinolytic inhibition was observed in two patients as shown for one of them in Fig. 7. Fibrinolytic inhibition was associated in this patient with thrombotic occlusion of the right ileofemoral artery. This vascular insult was accompanied by a temporary drop in platelet count and by a striking fall in plasma fibrinogen level.

Fibrinogen metabolism in extrahepatic portal hypertension. A fibrinogen turnover study was performed in two patients (V.J., J.V.) with extrahepatic portal hypertension. The portal vein obstruction was probably related to neonatal omphalitis. Both patients displayed congestive splenomegaly and esophageal varices, but had normal liver function and architecture. A shortened fibrinogen half-life of 2.4 and 3.3 days was observed, which was prolonged during fibrinolytic inhibition to 3.1 and 4.6 days, respectively, as represented for one of them in Fig. 8.

\section{DISCUSSION}

Fibrinogen turnover studies have been performed in 50 patients with cirrhosis of the liver to substantiate the hypothesis that chronic disseminated intravascular coagulation with possible secondary activation of the fibrinolytic system has to be considered in the pathogenesis of the defective coagulation. Pertinent clinical and liver function data, deposited with N.A.P.S., ${ }^{1}$ al-

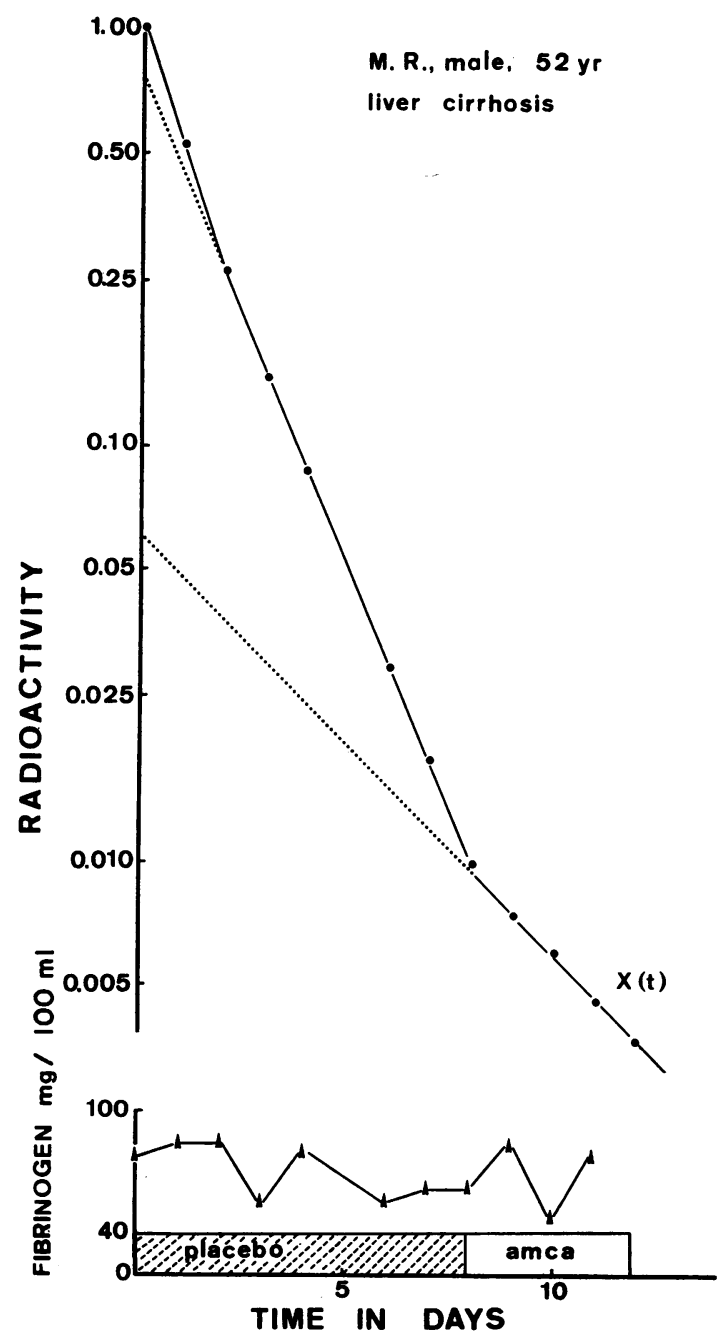

FIGURE 6 Fibrinogen metabolism in a patient with postnecrotic cirrhosis before and during inhibition of the fibrinolytic system. $x(t)$, plasma radioactivity. 
TABLE III

Influence of Fibrinolytic Inhibition on the Half-Life of Fibrinogen in Patients

with Cirrhosis of the Liver

\begin{tabular}{|c|c|c|c|c|c|c|c|c|c|c|}
\hline Patient & Age & Platelets & $\begin{array}{l}\text { One- } \\
\text { stage } \\
\text { pro- } \\
\text { throm- } \\
\text { bin }\end{array}$ & $\begin{array}{c}\text { Owren } \\
\text { time }\end{array}$ & Factor V & $\begin{array}{l}\text { Factor } \\
\text { VII-X }\end{array}$ & $\begin{array}{l}\text { Plasma } \\
\text { fibrin- } \\
\text { ogen }\end{array}$ & $\begin{array}{l}\text { Intra- } \\
\text { vascular } \\
\text { fraction } \\
\text { of } \mathbf{F g}\end{array}$ & $\begin{array}{c}\text { Fg-t } \\
\text { before } \\
\text { fibrino- } \\
\text { lytic } \\
\text { inhibition }\end{array}$ & $\begin{array}{c}\text { Fg- } \mathrm{t}_{\mathbf{3}} \\
\text { during } \\
\text { fibrino- } \\
\text { lytic } \\
\text { inhibition }\end{array}$ \\
\hline & $y r$ & $\underset{\mathrm{mm}^{2}}{\times 10^{-3} /}$ & $\%$ & $\%$ & $\%$ & $\%$ & $\begin{array}{c}m g / \\
100 m l\end{array}$ & $\%$ & days & days \\
\hline S. M. & 46 & 104 & 100 & 100 & 100 & - & 396 & 0.73 & 2.9 & 3.8 \\
\hline C. L. & 64 & 200 & 27 & 30 & 40 & 53 & 238 & 0.76 & 2.9 & 5.2 \\
\hline V. A. & 45 & 180 & 80 & 48 & 75 & 60 & 244 & 0.82 & 3.5 & 4.0 \\
\hline M. R. & 52 & 96 & 28 & 60 & 48 & 37 & 77 & 0.84 & 1.3 & 3.0 \\
\hline G. M. & 74 & 150 & 27 & - & - & - & 286 & 0.65 & 2.9 & 2.9 \\
\hline D. G. & 55 & 175 & 60 & - & - & - & 329 & 0.74 & 4.0 & 4.0 \\
\hline S. L. & 76 & 73 & 14 & 32 & 49 & 20 & 101 & 0.77 & 2.1 & 2.1 \\
\hline S. C. & 55 & 160 & 60 & 95 & 42 & - & 348 & 0.73 & 2.3 & 2.3 \\
\hline L. M. & 58 & 160 & 48 & 68 & 60 & 55 & 142 & 0.84 & 3.3 & 3.3 \\
\hline V. A. & 70 & 228 & 33 & 57 & 23 & 72 & 185 & 0.79 & 3.0 & 3.0 \\
\hline D. F. & 83 & 140 & 90 & 58 & 41 & 45 & 203 & 0.82 & 2.8 & 4.1 \\
\hline H. F. & 41 & 174 & 100 & 100 & 100 & 100 & 370 & 0.80 & 2.7 & 3.3 \\
\hline V. F. & 44 & 64 & 11 & 36 & 28 & 24 & 126 & 0.89 & 2.4 & 2.4 \\
\hline B. M. & 58 & 80 & 40 & 60 & 30 & - & 183 & 0.79 & 3.4 & 3.4 \\
\hline R. M. & 58 & 100 & 48 & 70 & 75 & 88 & 237 & 0.79 & 2.4 & 2.6 \\
\hline V. A. & 80 & 120 & 53 & 76 & 47 & 80 & 145 & 0.84 & 3.0 & 1.5 \\
\hline J. C. & 60 & 66 & 42 & 39 & 46 & 48 & 250 & 0.79 & 3.6 & 2.2 \\
\hline $\bar{m}$ & & & & & & & & & 2.9 & 3.1 \\
\hline
\end{tabular}

low approximate evaluation of the severity of the disease.

The purity of the labeled fibrinogen preparations has been demonstrated, both before and after iodination, by the high clottability and the homogeneous behavior on immunoelectrophoresis. Absence of early increased urinary excretion of radioactivity, maximal TCA-soluble radioactivities in plasma of less than $2 \%$ in controls, high intravascular fraction of fibrinogen of more than 0.70 at equilibrium, parallel evolution of plasma and clottable radioactivity, straight semiexponential decay after equilibration up to less than $5 \%$ of the initial plasma radioactivity, and presence of presumably only two logarithmic components in the plasma disappearance curve, strongly suggest that the injected material was biologically unaltered and that the amount of denatured or contaminating proteins was negligible.

The average plasma volume of $47 \pm 10 \mathrm{ml} / \mathrm{kg}$ in cirrhotics is significantly different from the corresponding control value of $42 \pm 7 \mathrm{ml} / \mathrm{kg}$. An expanded plasma volume beyond the normal range (mean $+2 \mathrm{SD}$ ) is found only in $20 \%$ of the patients. This relatively low incidence, compared with data in the literature $(29,32)$, is probably related to prolonged salt restriction and diuretic treatment in some of the patients.
The mean plasma fibrinogen concentration of 250 $\pm 102 \mathrm{mg} / 100 \mathrm{ml}$ in cirrhosis is not different from the corresponding control value of $284 \pm 71 \mathrm{mg} / 100 \mathrm{ml}$. Neither is there a difference in intravascular fibrinogen pool values between the cirrhotic population $(8.11 \pm 4.3$ $\mathrm{g}$ or $118 \pm 59 \mathrm{mg} / \mathrm{kg}$ ) and the control population $(8.24$ $\pm 2.8 \mathrm{~g}$ or $119 \pm 40 \mathrm{mg} / \mathrm{kg}$ ) which agrees with other data in the literature $(4,33,34)$.

An average fraction of $0.73 \pm 0.10$ of the total fibrinogen pool is confined to the intravascular compartment in cirrhosis, which is very similar to the corresponding value of $0.72 \pm 0.07$ for control subjects. The extravascular-intravascular radioactivity distribution ratio is not different in cirrhotics with ascites compared with patients without ascites. The high intravascular fraction of fibrinogen is in contrast with the occasionally high extravascular fraction of albumin in cirrhosis (35-39).

The fractional transfer rate constants $\left(k_{12}\right.$ and $\left.k_{21}\right)$ of $0.82 \pm 0.30$ and $1.51 \pm 0.57$, respectively, are higher in the cirrhotic population, compared with the corresponding control values of $0.60 \pm 0.26$ and $1.02 \pm 0.39$. This faster equilibration between intra- and extravascular space may be related to an approximately 5 -fold increase in thoracic duct lymph flow of cirrhotics (40, 41). 


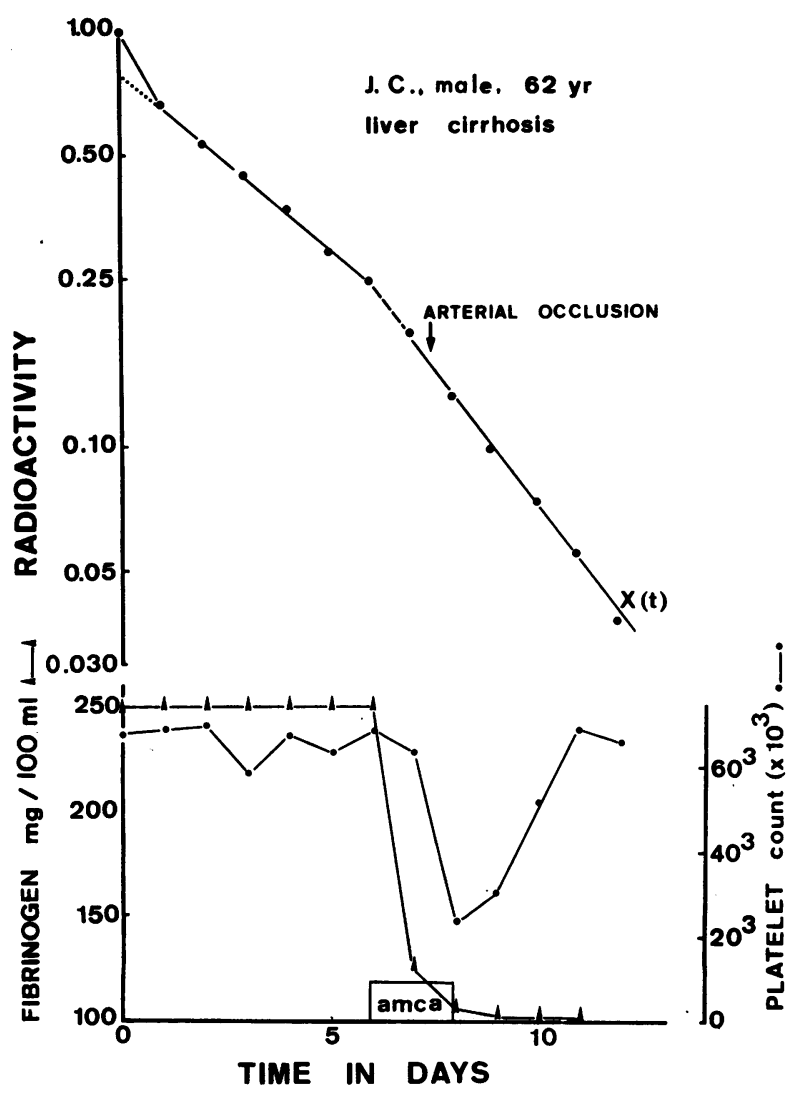

FIGURE 7 Fibrinogen metabolism in a patient with portal (alcoholic) cirrhosis before and during inhibition of the fibrinolytic system. $x(t)$, plasma radioactivity.

The mean fibrinogen half-life of $2.99 \pm 0.59$ days is significantly shorter than the half-life of $4.14 \pm 0.56$ days in controls, whereas the mean fractional catabolic rate of $0.34 \pm 0.09$ in cirrhosis is significantly higher than the control value of $0.24 \pm 0.04$. These findings confirm other data in the literature $(34,42)$, but are at variance with those reported by McFarlane, Todd, and Cromwell (33); this may be explained by severity differences between the selected cirrhotic patient material in both studies. The mean quantity of fibrinogen catabolized daily of $2.66 \pm 1.43 \mathrm{~g}$ or $39 \pm 20$ $\mathrm{mg} / \mathrm{kg}$ in cirrhotics is significantly higher than the corresponding mean control values of $1.94 \pm 0.59 \mathrm{~g}$ or $28 \pm 9 \mathrm{mg} / \mathrm{kg}$. These differences in turnover characteristics are not related to the significantly higher mean age in cirrhotics, because no correlation exists between age and fibrinogen half-life or fractional catabolic rate in either experimental series. The fact that plasma fibrinogen levels can be normal despite markedly accelerated catabolic rates, reflects the ability of the liver to increase fibrinogen synthesis and stresses the limited value of fibrinogen levels in evaluating fibrinogen turnover.
It is unlikely that the accelerated fibrinogen breakdown results from a generalized enhanced protein catabolism because normal or even prolonged half-lives have been described for albumin and beta lipoproteins in cirrhosis $(36,37,43)$. Neither can excessive gastrointestinal protein loss contribute to the low protein levels in cirrhosis because the quantity of albumin appearing in the gastrointestinal tract is low, representing less than $10 \%$ of the total catabolism (44).

The significantly increased fibrinogen turnover supports the hypothesis of chronic disseminated intravascular coagulation with excessive fibrinogen consumption in cirrhosis. Further unequivocal evidence is the finding of a complete normalization of the fibrinogen turnover during heparin infusion in 8 out of 10 patients, which strikingly contrasts with the absence of prolongation of the plasma radioactivity half-life during heparinization in controls. A concomitant rise in average plasma fibrinogen during heparinization has been observed in six out of eight patients. The very high in-

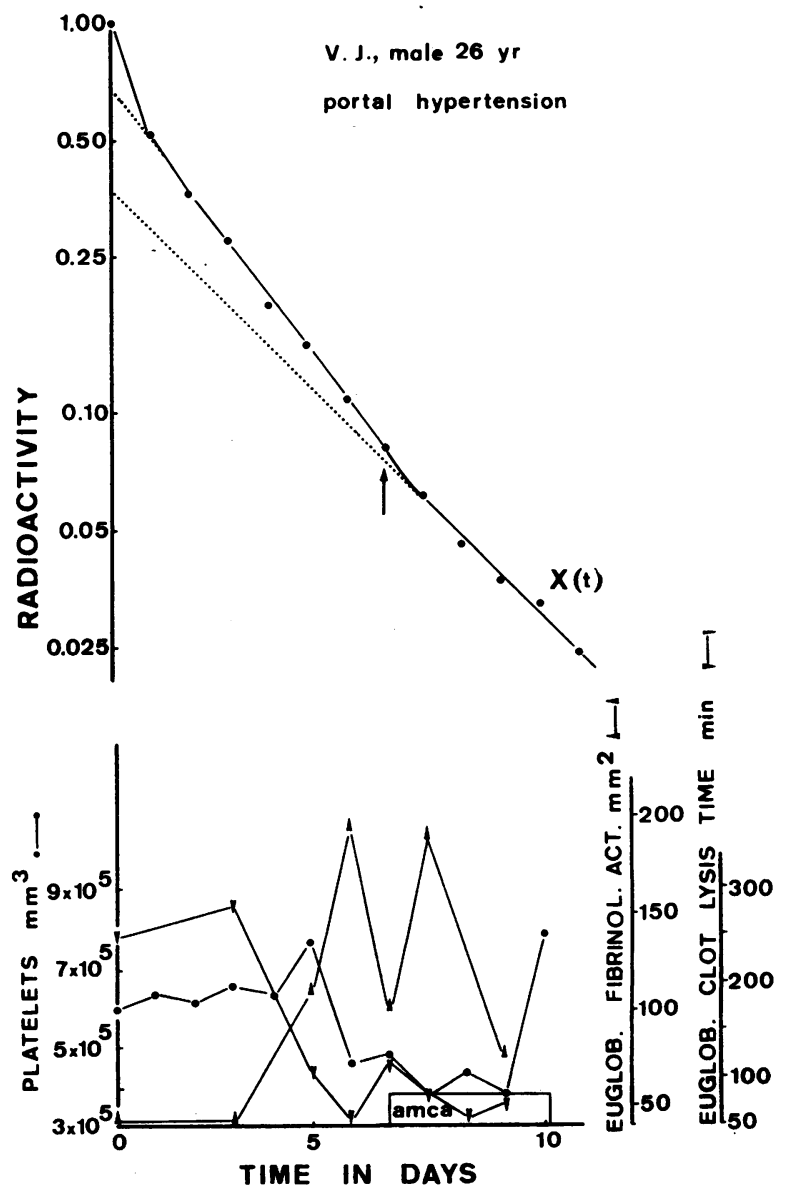

FIGURE 8 Fibrinogen metabolism in a patient with extrahepatic portal hypertension, before and during inhibition of the fibrinolytic system. $x(t)$, plasma radioactivity. 
crease in plasma fibrinogen during heparinization in a patient with primary biliary cirrhosis suggests minimal functional alterations of the hepatocytes which may correspond to their inconspicuous changes on electron microscopy (45). Absence of obvious increase in circulating platelets during heparinization does not militate against the concept of intravascular coagulation because heparinization by itself tends to reduce the platelet level (46-50).

It has been shown that chronic disseminated intravascular coagulation may induce a secondary activation of the fibrinolytic system characterized by a decrease in plasminogen and fibrinolytic inhibitors and by the appearance of fibrin(ogen) breakdown products (10, 51-53). Patients with cirrhosis of the liver are considered to be particularly sensitive to fibrinolytic activation because of a decreased hepatic clearance of plasminogen activator and an insufficient fibrinolytic inhibitor capacity $(6,7)$. To what additional extent the enhanced fibrinogen catabolism in cirrhosis is due to fibrinogenolysis has been evaluated by studying the disappearance rate of labeled fibrinogen during pharmacological inhibition of the fibrinolytic system by tranexamic acid, a potent inhibitor of plasminogen activation (15). No influence on the fibrinogen turnover during fibrinolytic inhibition has been observed in 7 out of 17 patients. A prolongation of the fibrinogen half-life of 1 day or more has been noted in only three patients, an incidence which is similar to that observed in the control group during fibrinolytic inhibition. A concomitant increase in plasma fibrinogen concentration has never occurred during fibrinolytic inhibition. Hence we wonder whether the apparent prolongation of the plasma radioactivity half-life is due to a prolonged survival of fibrinogen, or whether it reflects a prolonged existence in the circulation of fibrinogen derivatives (fibrin monomer or copolymer?) generated during intravascular microcoagulation. Obviously a correcting effect on the fibrinogen decay is much more frequently seen during heparin than during tranexamic acid administration. It is therefore unlikely that fibrinogenolysis is of primary importance in the enhanced fibrinogen catabolism in cirrhosis

The occurrence of an arterial thrombosis during tranexamic acid administration in one of our patients warns against uncritical pharmacological inhibition of the fibrinolytic system in situations where fibrinolysis may be compensatory to clotting.

Several factors can be considered in the pathogenesis of the in vivo activation of the coagulation system in cirrhosis. The cirrhotic-expanded collateral circulation and the congestive spleen represent a tremendous increase in endothelial surface. Sluggish circulation in this collateral vascular bed and in the dilated splenic sinusoids where a high number of platelets are trapped, might well create (hypoxic?) alterations of the endothelial cells and predispose to local clotting. In favor of this hypothesis is our finding of a shortened fibrinogen half-life in two patients with extrahepatic portal hypertension, splenomegaly, and extensive collateral circulation but with normal liver function and architecture. Moreover it has been reported that clotting abnormalities, presumably of the consumption type, in congestive splenomegaly can be more or less completely reversed by splenectomy $(54,55)$. Finally some similarity can be seen between the altered vascular architecture in cirrhosis and a giant hemangioma, which is also frequently associated with intravascular coagulation $(56,57)$.

Several investigators have emphasized the role of the liver in clearing from the circulation certain activated clotting factors, but not their inactive forms, by mechanisms that depend on the reticuloendothelial as well as on the hepatic cell system (58-65). Reduction and functional disturbance of the hepatic cell mass, combined with hemodynamic changes of the hepatoportal flow and circulatory bypassing of the liver, may be responsible for diminished removal of procoagulant material and activated clotting factors, which can favor accelerated fibrin formation.

Shortened erythrocyte life-span, or overt hemolysis of different degrees (66), and the presence of erythrocytes bearing spur-like projections (67-69) have been reported in liver cirrhosis. In vivo hemolysis with liberation of thromboplastin-like substances can initiate intravascular clotting, while the release of erythrocyte adenosine diphosphate can cause platelet aggregation $(70,71)$. A vicious circle may occur in which intravascular coagulation results in fibrin deposition in small blood vessels, causing fragmentation of red cells with further release of thromboplastic material and perpetuation of intravascular coagulation $(72,73)$.

Our finding in cirrhotics of a shortened fibrinogen half-life, due to accelerated consumption in a process of chronic disseminated intravascular coagulation fully supports and extends earlier clinical observations by Scandinavian authors (74-76) concerning the bleeding tendency in cirrhosis. Moreover, our results, together with recent data in the literature $(77,78)$, further document the correcting effect of heparin on the coagulation abnormalities in cirrhosis of the liver.

\section{ACKNOWLEDGMENTS}

We wish to thank Professor Vandenbroucke, Dr. J. Vermylen, and Professor De Groote for continuous interest and stimulation. The biochemical assistance of Dr. R. A. De Vreker and H. Claeys, the hospitality at the Department of Nuclear Medicine of Dr. M. Deroo and Dr. M. Goris, and the skillful technical assistance of Mr. F. De Cock and Miss A. Verhaegen are gratefully acknowledged. 


\section{REFERENCES}

1. Aster, R. H. 1966. Pooling of platelets in the spleen: role in the pathogenesis of "hypersplenic" thrombocytopenia. J. Clin. Invest. 45: 645.

2. Mandel, E. E., and J. Lazerson. 1961. Thrombasthenia in liver disease. N. Engl. J. Med. 265: 56.

3. Cortet, P., C. Klepping, J. Devant, J. P. Lebel, and B. Jacquot. 1964. Le facteur plaquettaire au cours des cirrhoses alcooliques: étude de l'adhésivité in vivo par le test de Borchgrevink. Arch. Mal. App. Dig. Mal. Nut. 53: 1041.

4. Thomas, D. P., V. J. Ream, and R. K. Stuart. 1967. Platelet aggregation in patients with Laennec's cirrhosis of the liver. N. Engl. J. Med. 276: 1344.

5. Goebell, H., H. Bickel, C. Bode, R. Egbring, and G. A. Martini. 1968. Veränderte Aktivitäten der Enzyme des Energiestoffwechsels in Thrombocyten von Patienten mit Lebercirrhose und Splenomegalie. Klin. Wochenschr. 46: 526.

6. Fletcher, A. P., O. Biederman, D. Moore, N. Alkjaersig, and S. Sherry. 1964. Abnormal plasminogen-plasmin system activity (fibrinolysis) in patients with hepatic cirrhosis: its cause and consequences. J. Clin. Invest. 43: 681.

7. Tytgat, G., D. Collen, R. De Vreker, and M. Verstraete. 1968. Investigations on the fibrinolytic system in liver cirrhosis. Acta Haematol. 40: 265.

8. McKay, D. G. 1965. Disseminated Intravascular Coagulation. Hoeber Medical Division of Harper and Row, New York. 21.

9. Verstraete, M., C. Vermylen, J. Vermylen, and J. Vandenbroucke. 1965. Excessive consumption of blood coagulation components as cause of hemorrhagic diathesis. Amer. J. Med. 38: 899.

10. Merskey, C., A. J. Johnson, G. J. Kleiner, and H. Wohl. 1967. The defibrination syndrome: clinical features and laboratory diagnosis. Brit. J. Haematol. 13: 528.

11. Blombäck, B., and M. Blombäck. 1956. Purification of human and bovine fibrinogen. Ark. Kemi. 10: 415.

12. Blombäck, B., M. Blombäck, and I. Struwe. 1962. Studies of factor VIII. In Progress in Coagulation. Schattauer-Verlag, Stuttgart, Germany. 172.

13. McFarlane, A. S. 1958. Efficient trace-labelling of proteins with iodine. Nature (London). 182: 53.

14. Scheidegger, J. J. 1955. Une microméthode de l'immuno-électrophorèse. Int. Arch. Allergy Appl. Immunol. $7: 103$.

15. Andersson, L., I. M. Nilsoon, S. Colleen, B. Granstrand, and B. Melander. 1968. Role of urokinase and tissue activators in sustaining bleeding and the management thereof with EACA and AMCA. Ann. N. Y. Acad. Sci. 146: 642 .

16. Matthews, C. M. E. 1957. The theory of tracer experiments with 131 I-labelled plasma proteins. Phys. Med. Biol. 2 : 36 .

17. Lee, R. I., and P. D. White. 1913. A clinical study of the coagulation time of blood. Amer. J. Med. Sci. 145: 495.

18. Quick, A. J. 1935. The prothrombin in haemophilia and in obstructive jaundice. J. Biol. Chem. 109: Lxxiii. (Abstr.)

19. Owren, P. A. 1949. A quantitative one-stage method for the assay of prothrombin. Scand. J. Clin. Lab. Invest. 1: 81 .

20. Owren, P. A., and K. Aas. 1951. The control of dicumarol therapy and the quantitative determination of prothrombin and proconvertin. Scand. J. Clin. Lab. Invest. 3 : 201.

21. Stormorken, H. 1957. The preparation of a proaccelerin deficient (parahemophilia) plasma for the assay of proaccelerin. Scand. J. Clin. Lab. Invest. 9: 273.

22. Vermylen, C., and M. Verstraete. 1960. Antithrombin $\mathrm{V}$ : critical evaluation of its assessment and properties. Thromb. Diath. Haemorrh. 5: 267.

23. Vermylen, C., R. De Vreker, and M. Verstraete. 1963. A rapid enzymatic method for assay of fibrinogen fibrin polymerization time (FPT test). Clin. Chim. Acta. 8: 418.

24. Brecher, G., and E. P. Cronkite. 1950. Morphology and enumeration of human blood platelets. J. Appl. Physiol. 3: 365.

25. DeVreker, R. A. 1965. A technique for routine evaluation of plasminogen in humans during streptokinase therapy. Acta Haematol. 34: 305.

26. Astrup, T., and S. Müllertz. 1952. The fibrin plate method for estimating fibrinolytic activity. Arch. Biochem. Biophys. 40: 346.

27. Blix, S. 1961. Studies on the fibrinolytic system in the euglobulin fraction of human plasma. Scand. J. Clin. Lab. Invest. 13 (Suppl. 58) : 3.

28. Bailey, N. T. J. 1959. Statistical Methods in Biology. English Universities Press, Ltd., London.

29. Cachera, R., F. Darnis, and G. Lepercq. 1951. Volume plasmatique, protéines totales circulantes et syndrome oedémateux des cirrhoses alcooliques. Presse Med. 59: 1660.

30. Gilder, H., S. F. Redo, D. Barr, and C. G. Child III. 1954. Water distribution in normal subjects and in patients with Laennec's cirrhosis. J. Clin. Invest. 33: 555.

31. Murray, J. F., A. M. Dawson, and S. Sherlock. 1958. Circulatory changes in chronic liver disease. Amer. $J$. Med. $24: 358$.

32. Sheehy, T. W., and A. Berman. The anemia of cirrhosis. J. Lab. Clin. Med. 56: 72.

33. McFarlane, A. S., D. Todd, and S. Cromwell. 1964. Fibrinogen catabolism in humans. Clin. Sci. (London). 26: 415 .

34. Blombäck, B., L. A. Carlson, S. Franzén, and E. Zetterqvist. 1966. Turnover of ${ }^{181}$ I-labelled fibrinogen in man. Acta Med. Scand. 179: 557.

35. Sterling, K. 1951. Serum albumin turnover in Laennec's cirrhosis as measured by ${ }^{181} \mathrm{I}$-tagged albumin. J. Clin. Invest. 30: 1228.

36. Eisenmenger, J., and R. J. Slater. 1953. Distribution and decay of $\mathrm{I}^{131}$-tagged albumin and gamma-globulin in patients with cirrhosis. J. Clin. Invest. 32: 564.

37. Wilkinson, W. P., and C. L. Mendenhall. 1963. Serum albumin turnover in normal subjects and patients with cirrhosis measured by ${ }^{131} \mathrm{I}$ labeled human albumin. Clin. Sci. (London). 25: 281.

38. Hash, E., S. Jarnum, and N. Tygstrup. 1967. Albumin synthesis rate as a measure of liver function in patients with cirrhosis. Acta Med. Scand. 181: 83.

39. Dykes, P. W. 1968. The rates of distribution and catabolism of albumin in normal subjects and in patients with cirrhosis of the liver. Clin. Sci. (London). 34: 161.

40. Dumont, A. E., and J. J. Mulholland. 1965. Hepatic lymph in cirrhosis. Progr. Liver Dis. 2: 427.

41. Witte, M. H., W. R. Cole, D. F. Burton, L. Alvarez, and A. E. Dumont. 1968. Thoracic duct cannulation and differential diagnosis of obstructive jaundice. J. Amer. Med. Ass. 204: 366. 
42. Amris, A., and C. J. Amris. 1964. Turnover and distribution of ${ }^{181}$ iodine-labelled human fibrinogen. Thromb. Diath. Haemorrh. 11: 404.

43. Volwiler, W., P. D. Goldsworthy, M. P. MacMartin, P. A. Wood, I. R. Mackay, and K. Fremont-Smith. 1955. Biosynthetic determination with radioactive sulfur of turnover rates of various plasma proteins in normal and cirrhotic man. J. Clin. Invest. 34: 1126.

44. Kerr, R. M., J. J. Dubois, and P. R. Holt. 1967. Use of ${ }^{125} \mathrm{I}$ and ${ }^{51} \mathrm{Cr}$-labelled albumin for the measurement of gastrointestinal and total albumin catabolism. J. Clin. Invest. 46: 2064.

45. Popper, H. 1966. Primary biliary cirrhosis. Rev. Int. Hepatol. 16: 239.

46. Fidlar, E., and L. B. Jaques. 1948. Effect of commercial heparin on platelet count. J. Lab. Clin. Med. 33: 1410.

47. Gollub, S., and A. W. Ulin. 1962. Heparin-induced thrombocytopenia in man. J. Lab. Clin. Med. 59: 430.

48. Roswell, H. C., M. F. Glynn, J. F. Mustard, and E. A. Murphy. 1967. Effect of heparin on platelet economy in dogs. Amer. J. Physiol. 213: 915.

49. Davey, M. G., and H. Lander. 1968. Effect of injected heparin on platelet levels in man. J. Clin. Pathol. (London). $21: 55$.

50. Natelson, E. A., E. C. Lynch, C. P. Alfrey, and J. B. Cross. 1969. Heparin-induced thrombocytopenia. Ann. Intern. Med. 71: 1121.

51. Allen, J. G., and D. P. Glotzer. 1964. Acute disseminated intravascular coagulation and fibrinolysis. Arch. Surg. 88: 694.

52. Margaretten, W., I. Csavossy, and D. G. McKay. 1967. An electron microscopic study of thrombin-induced disseminated intravascular coagulation. Blood. 29: 169.

53. Izak, G., and K. Galewsky. 1966. Studies on experimentally induced hypercoagulable state in rabbits. Thromb. Diath. Haemorrh. 16: 228.

54. Vergoz, D., V. G. Levy, A. Najman, and J. Caroli. 1967. Variations du facteur $\mathrm{V}$ au cours des splénectomies dans les cirrhoses. Rev. Fr. Etud. Clin. Biol. 12: 125.

55. Fisher, S. 1968. Cryptogenetic congestive severe coagulopathy in splenomegaly. J. Amer. Med. Ass. 205: 111.

56. Kasabach, H. H., and K. K. Merritt. 1940. Capillary hemangioma with extensive purpura. Amer. J. Dis. Child. 59: 1063.

57. Blix, S., and K. Aas. 1961. Giant haemangioma, thrombocytopenia, fibrinogenopenia and fibrinolytic activity. Acta Med. Scand. 169: 63 .

58. Spaet, T. H., H. I. Horowitz, D. Zucker-Franklin, J. Cintron, and J. J. Biezenski. 1961. Reticuloendothelial clearance of blood thromboplastin by rats. Blood. 17: 196.

59. Spaet, T. H. 1962. Studies on the in vivo behavior of blood coagulation product I in rats. Thromb. Diath. Haemorrh. 8: 276.

60. Deykin, D. 1966. The role of the liver in serum-induced hypercoagulability. J. Clin. Invest. 45: 256.

61. Deykin, D., and G. Fleming. 1966. Hepatic clearance of factor X (Stuart). Fed. Proc. 25: 256.
62. Gans, H., J. T. Lowman, and G. Fahr. 1966. Uptake of intact and disintegrated rat platelets by the isolated perfused rat liver. Fed. Proc. 25: 2900.

63. Gans, H., and J. T. Lowman. 1967. The uptake of fibrin and fibrin degradation products by the isolated perfused rat liver. Blood. 29: 526.

64. Gans, H., R. Stern, and B. H. Tan. 1969. On the in vivo clearance of thrombin. Thromb. Diath. Haemorrh. 22: 1 .

65. Walsh, R. T., and M. I. Barnhart. 1969. Clearance of coagulation and fibrinolysis products by the reticuloendothelial system. In Disseminated Intravascular Coagulation. E. F. Mämmen, G. F. Anderson, and M. I. Barnhart, editors. Schattauer Verlag, Stuttgart, Germany. 83.

66. Kimber, C., D. J. Deller, R. N. Ibbotson, and H. Lander. 1965. The mechanism of anaemia in chronic liver disease. Quart. J. Med. 34: 33.

67. Smith, J. A., E. T. Lonergan, and K. Sterling. 1965. Spur-cell anemia, hemolytic anemia with red cells resembling acanthocytes in alcoholic cirrhosis. N. Engl. J. Med. 271: 396.

68. Silber, R., E. Amorosi, J. Lhowe, and H. J. Kayden. 1966. Spur-shaped erythrocytes in Laënnec's cirrhosis. N. Engl. J. Med. 275: 639.

69. Grahn, E. P., A. A. Dietz, S. S. Stefano, and W. J. Donnelly. 1968. Burr cells, hemolytic anemia and cirrhosis. Amer. J. Med. 45: 78.

70. Quick, A., and M. E. Hickey. 1960. Influence of erythrocytes on the coagulation of blood. Amer. J. Med. Sci. 239: 51 .

71. Rabiner, S. F., L. H. Friedman, and S. T. Rosenfeld. 1965. Blood hypercoagulability induced by intravascular hemolysis. J. Clin. Invest. 44: 1089.

72. Rubenberg, M. L., E. Regoeczi, B. S. Bull, J. V. Dacie, and M. C. Brain. 1968. Microangiopathic haemolytic anaemia: the experimental reduction of haemolysis and red-cell fragmentation by defibrination in vivo. Brit. $J$. Haematol. 14: 627.

73. Bull, B. S., M. L. Rubenberg, J. V. Dacie, and M. C. Brain. 1968. Microangiopathic haemolytic anaemia, mechanisms of red-cell fragmentation: in vitro studies. Brit. J. Haematol. 14: 643.

74. Bergström, K., B. Blombäck, and G. Kleen. 1960. Studies on the plasma fibrinolytic activity in a case of liver cirrhosis. Acta Med. Scand. 168: 291.

75. Zetterqvist, E., and I. Von Francken. 1963. Coagulation disturbances with manifest bleeding in extrahepatic portal hypertension and in liver cirrhosis. Acta Med. Scand. 173: 753.

76. Johansson, S. A. 1964. Studies on blood coagulation factors in a case of liver cirrhosis. Acta Med. Scand. 175: 177.

77. Hörder, M. H. 1969. Consumption coagulopathy in liver cirrhosis. Seventeenth annual symposium on blood, Detroit. Thromb. Diath. Haemorrh. Suppl. 36: 313.

78. Robboy, F., J. Minna, and R. Colman. 1970. Resolution of pathological fibrinolysis with heparin. Clin. Res. 18: 414. (Abstr.) 